\title{
Induction of osteoclast formation by parathyroid hormone depends on an action on stromal cells
}

\author{
K Fuller, J M Owens and T J Chambers \\ Department of Histopathology, St George's Hospital Medical School, Cranmer Terrace, London SW17 ORE, UK \\ (Requests for offprints should be addressed to T J Chambers)
}

\begin{abstract}
It is believed that parathyroid hormone (PTH) increases the resorptive activity of pre-existing osteoclasts through a primary interaction with cells of the osteoblastic lineage. Much less is known, however, of the mechanisms by which PTH induces osteoclast formation. It is known that osteoclast formation occurs through a contact-dependent interaction between stromal cells and haemopoietic precursors, but it is not known whether PTH acts on stromal cells or precursors to induce osteoclast formation. To address this issue, we compared the ability of haemopoietic cultures to generate osteoclasts, identified as calcitonin receptor positive (CTRP) cells, and to resorb bone in response to $\mathrm{PTH}$ and $1,25(\mathrm{OH})_{2}$ vitamin $\mathrm{D}_{3}$ $\left(1,25(\mathrm{OH})_{2} \mathrm{D}_{3}\right)$. We found that when murine haemopoietic tissues were incubated at densities sufficiently high to support haemopoiesis, both PTH and $1,25(\mathrm{OH})_{2} \mathrm{D}_{3}$ induced bone resorption in bone marrow cells, but
\end{abstract}

in cultures of haemopoietic spleen only $1,25(\mathrm{OH})_{2} \mathrm{D}_{3}$ induced CTRP cells, and neither hormone induced bone resorption. To determine whether these differences were attributable to differences in stromal cells or haemopoietic precursors, lower densities of haemopoietic spleen cells were incubated on osteoblastic (UMR 106), splenic or bone marrow stromal cells. We found that the behaviour of the cocultures reflected the characteristics and origin of the stromal cells. Thus, the ability of both osteoblastic and splenic stromal cells to induce CTRP cells with $1,25(\mathrm{OH})_{2} \mathrm{D}_{3}$, while only osteoblastic cells induced osteoclasts with PTH, from the same precursors, suggests that the ability of PTH to induce osteoclastic differentiation cannot be attributed to a hormonal action on osteoclast precursors, but depends on a response in stromal cells.

Journal of Endocrinology (1998) 158, 341-350

\section{Introduction}

The osteoclast is the cell that resorbs bone. It is known to form through a contact-dependent interaction between macrophage colony stimulating factor-dependent bipotential osteoclast-macrophage precursors that derive ultimately from the haemopoietic stem cell, and stromal cells that express osteoclast-forming activity (Chambers et al. 1993, Suda et al. 1995). Once formed, the localisation and resorptive activity of osteoclasts is thought to be controlled by cells of the osteoblastic lineage, in a manner appropriate to local tissue needs and systemic calcium homeostasis (Chambers 1980, 1992, Rodan \& Martin 1981, Suda et al. 1995).

Parathyroid hormone (PTH) exerts a major influence over the systemic rate of bone resorption. Following an injection of $\mathrm{PTH}$, there is a rapid increase in the activity of pre-existing osteoclasts, followed by an increase in osteoclast numbers (Bingham et al. 1969, Baron \& Vignery 1981). It is believed that PTH increases the resorptive activity of pre-existing osteoclasts through a primary hormonal interaction with cells of the osteoblastic lineage, which possess PTH receptors and responsiveness
(Chambers 1980, Rodan \& Martin 1981), while osteoclasts have been found in most (Rouleau et al. 1986, 1988, 1990) but not all (Rao et al. 1983, Teti et al. 1991, Agarwala \& Gay 1992) studies to lack PTH receptors, and do not show a direct functional response to the hormone (Chambers et al. 1985). Much less is known, however, of the mechanism by which PTH induces osteoclast formation. Haemopoietic blast cells, the ultimate precursor of osteoclasts, have been reported to express PTH receptors, and can be induced by PTH to generate cells that express tartrate-resistant acid phosphatase (TRAP) (Hakeda et al. 1989, Kaji et al. 1994, 1997), although neither bone resorption nor an enhanced potential for bone resorption by such PTH-treated cells has been demonstrated. TRAP is not always a reliable phenotypic marker for osteoclastic differentiation, since it can also be expressed in vitro in other cell types including macrophages (Radzun et al. 1983, Snipes et al. 1986, Bianco et al. 1988, Hattersley \& Chambers 1989a, Modderman et al. 1991), which are also produced in cultures of haemopoietic blast cells, but expression is nevertheless evidence for hormonal responsiveness in precursors of osteoclasts. PTH has been shown to induce bone resorption in bone marrow cultures 
(Takahashi et al. 1988b, Akatsu et al. 1989), and in cultures of mixed bone cells from 10- to 15-day-old rodents (Inoue et al. 1995, Kaji et al. 1995, 1996). Since these cultures include osteoblastic cells, which express PTH receptors, they do not identify the nature of the cell type responding primarily to PTH. However, experiments using TRAP as a marker for osteoclasts suggest that a PTH response is needed in stromal supporting cells; calvarial osteoblastic cells or KS4 cells support TRAP cell production in spleen cell cultures, while ST2 and MC3T3-G2/PA6 cells, which lack PTH receptors, do not (Takahashi et al. 1988a, Udagawa et al. 1989, Yamashita et al. 1990).

There is similar uncertainty concerning the mechanism by which a second major calcium-regulating hormone, $1,25(\mathrm{OH})_{2}$ vitamin $\mathrm{D}_{3}\left(1,25(\mathrm{OH})_{2} \mathrm{D}_{3}\right)$, regulates osteoclast formation. There is substantial evidence that it induces differentiation in cells of the mononuclear phagocyte series, including such osteoclast characteristics as multinuclearity, carbonic anhydrase II expression and vitronectin receptors (Abe et al. 1983, Bar-Shavit et al. 1983, Billecocq et al. 1990, Medhora et al. 1993). Induction of lacunar bone resorption, however, depends on contact with osteoblastic or bone marrow stromal cells, which also express $1,25(\mathrm{OH})_{2} \mathrm{D}_{3}$ receptors, and it is not known whether $1,25(\mathrm{OH})_{2} \mathrm{D}_{3}$ induces osteoclast formation through actions on stromal cells, osteoclastic precursors, or both (Chambers 1992).

It would clearly be of value to distinguish whether the responses observed in stromal cells, or precursor cells, or both, are necessary for the induction of osteoclastic differentiation. To do this, spleen cells, obtained from young animals at a stage where splenic haemopoiesis was still active, or bone marrow cells, were incubated with PTH or $1,25(\mathrm{OH})_{2} \mathrm{D}_{3}$ at cell densities sufficiently high to support haemopoiesis. Osteoclast formation was assessed by measuring calcitonin (CT) receptor-positive (CTRP) cell numbers and bone resorption. Because the cell type mediating hormonal responses cannot be identified in such heterogenous cultures, hormonal responses were also assessed in cultures of haemopoietic spleen cells incubated at low density on spleen and bone marrow stromal, or osteoblastic cell lines. We found that while $1,25(\mathrm{OH})_{2} \mathrm{D}_{3}$ supported CTRP cell production from haemopoietic precursors in all the culture types, only UMR 106 cells reproduced the ability of bone marrow cultures to respond to PTH. This suggests that the ability of PTH to induce osteoclast formation cannot be attributed to an action on osteoclast precursors, but depends on an interaction of PTH with stromal/osteoblastic cells.

\section{Materials and Methods}

Bovine PTH (1-34) was purchased from Sigma Chemical Co. (Poole, Dorset, UK) and used at $0 \cdot 1 \mathrm{U} / \mathrm{ml}$ throughout. $1,25(\mathrm{OH})_{2} \mathrm{D}_{3}$, used at $10^{-8} \mathrm{M}$, was provided by
Solvay Duphar (Weesp, Holland). Osteoblast-like UMR 106 cells were from Dr T J Martin, Melbourne, Australia. Bone marrow and spleen stromal cell lines, established with an immortalising temperature-sensitive defective retrovirus that encodes SV-40 large $\mathrm{T}$ antigen, were produced as previously described (Owens et al. 1996).

Incubations were performed in Eagle's minimum essential medium (MEM; Imperial Laboratories, Andover, Hants, UK) supplemented with $100 \mathrm{IU} / \mathrm{ml}$ benzylpenicillin, $100 \mu \mathrm{g} / \mathrm{ml}$ streptomycin, $2 \mathrm{mM}$ glutamine and 10\% newborn calf serum (NCS) (all from Imperial Laboratories). All incubations were performed in $5 \% \mathrm{CO}_{2}$ in humidified air.

Slices of devitalised bovine cortical bone, used as substrates for osteoclastic resorption, were prepared as previously described (Chambers et al. 1985). Bone slices $(4 \times 3 \times 0.1 \mathrm{~mm})$ were cut with a low-speed saw (Isomet Corp., Springfield, VA, USA), cleaned by ultrasonication in sterile water, washed, immersed in alcohol, and stored dry at room temperature.

\section{Bone marrow cultures}

The generation of osteoclasts in mouse bone marrow cultures was assessed as previously described (Hattersley \& Chambers 1990). Femora and tibiae from 6- to 8-weekold MF-1 mice were removed and cleaned of adherent tissue. The bone ends were cut and the marrow cavity flushed out by injecting Hepes-buffered Medium 199 (Imperial Laboratories) from one end. The bone marrow cells were washed and resuspended in MEM/NCS. Cells were added to the wells of microtitre plates (Sterilin, Teddington, Middlesex, UK) $\left(5 \times 10^{5}\right.$ per well, $200 \mu \mathrm{l} /$ well), each well of which contained a $6 \mathrm{~mm}$ Thermanox coverslip (Life Technologies Inc., Uxbridge, Middlesex, UK) or a slice of bovine cortical bone. The cultures were incubated in the presence or absence of $1,25(\mathrm{OH})_{2} \mathrm{D}_{3}$ and/or PTH for 14 days at $37^{\circ} \mathrm{C}$. Cultures were fed every 3 days by replacing $120 \mu \mathrm{l}$ culture medium with fresh medium and hormones.

After incubation, bone slices and coverslips were removed from wells and prepared for measurement of bone resorption and ${ }^{125} \mathrm{I}-\mathrm{CT}$ autoradiography respectively, as described below.

\section{Preparation of spleen cell populations and coculture with stromal cells}

Osteoclast-inductive bone marrow stromal cell lines ts 2 and tsJ4, and spleen stromal cell lines tsMS5 and tsMS6 (Owens et al. 1996) were added to 96-well plates $\left(10^{4} /\right.$ well $)$. Each well contained either a bone slice or a $6 \mathrm{~mm}$ Thermanox coverslip. The stromal cells were incubated in MEM/NCS for 3 days at $39.5{ }^{\circ} \mathrm{C}$, before addition of spleen cells. Osteoblastic UMR 106 cells $\left(10^{4} /\right.$ well $)$ were preincubated for 2 days at $37^{\circ} \mathrm{C}$ prior to addition of spleen cells. 

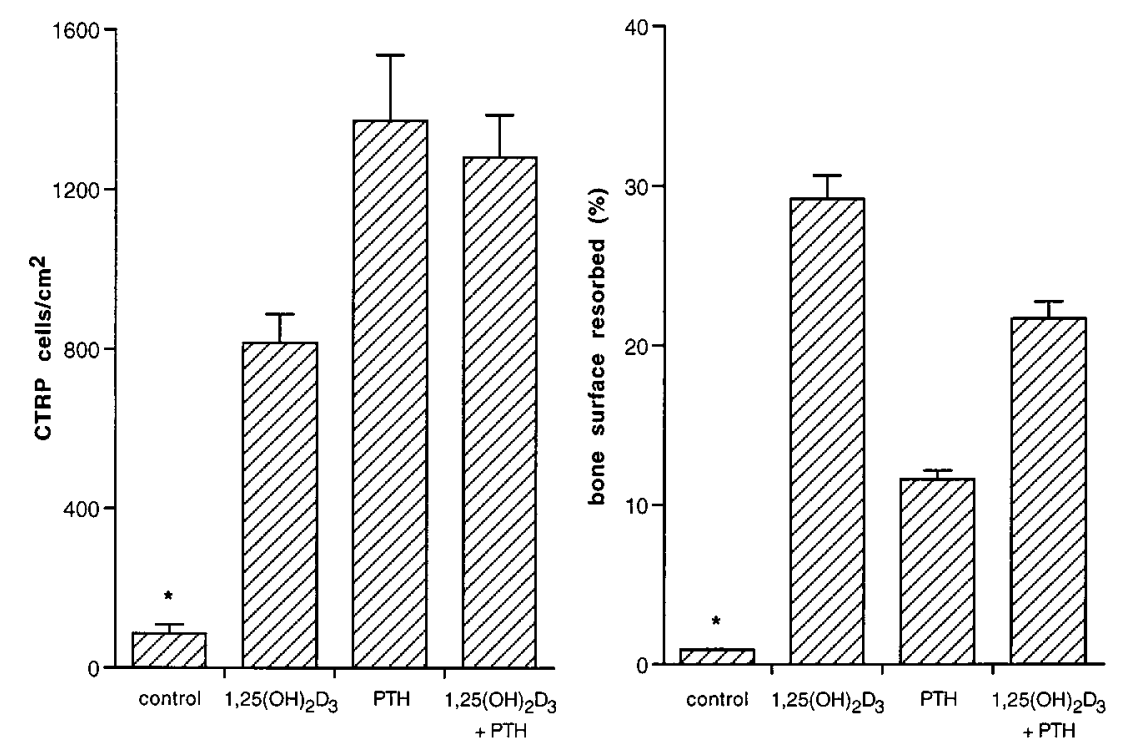

Figure 1 Induction of CTRP cells and bone resorption in cultures of bone marrow cells incubated in the presence or absence of PTH and $1,25(\mathrm{OH})_{2} \mathrm{D}_{3}$ for 14 days. Figures represent means \pm S.E.M. of 30 cultures per variable. ${ }^{*} P<0.05$ vs all other points.

Spleen cell suspensions were prepared by mechanically disaggregating spleens from 4-day-old MF-1 mice by repeated passage through 21 gauge needles. The suspension was washed, resuspended in MEM/NCS, and added to 96 -well plates at $10^{5}$ cells/well for incubation with stromal cell lines, and at $5 \times 10^{5}$ cells/well when incubated without stromal cell lines (total culture volume, $200 \mu \mathrm{l})$.

Cultures were incubated in the presence or absence of $1,25(\mathrm{OH})_{2} \mathrm{D}_{3}$ and/or PTH, and were fed every 3 days by replacing $120 \mu \mathrm{l}$ medium with fresh medium and hormones. Coverslips or bone slices were removed after 4-21 days of incubation for assessment of osteoclast differentiation.

In some experiments stromal cells were devitalised after $24 \mathrm{~h}$ incubation in PTH by incubation in glutaraldehyde (2\%, $1 \mathrm{~min}$ ) (Hattersley \& Chambers 1989b) before addition of spleen cells. Supernatants of cultures of UMR 106 cells, taken after incubation in PTH for $18 \mathrm{~h}$, were added to these cultures (50\% in incubation medium) in place of culture medium throughout the experiment.

\section{Phenotypic assessment}

Bone resorption was assessed as described previously (Fuller et al. 1993). Bone slices were removed from wells after incubation and immersed in $10 \% \mathrm{NaOCl}(\mathrm{BDH}$, Poole, Dorset, UK) for $10 \mathrm{~min}$ to remove cells. The bone slices were then washed, dehydrated in ethanol, and sputter-coated with gold. The extent of bone resorption was quantified by counting, by reflected light microscopy, the percentage of grid intersections in an eyepiece graticule that overlay an area of bone resorption.

Expression of CT receptors was assessed by ${ }^{125} \mathrm{I}-\mathrm{CT}$ as described (Hattersley \& Chambers 1989c). Coverslips were incubated with labelled CT $(0.2 \mathrm{nM})$ in Hepesbuffered Medium 199 containing 0.1\% BSA (Sigma) for $1 \mathrm{~h}$ at $22{ }^{\circ} \mathrm{C}$. Non-specific binding was assessed by including excess $(300 \mathrm{nM})$ unlabelled $\mathrm{CT}$ in some wells. After incubation, coverslips were fixed in formalin and washed extensively in water. The coverslips were then coated with K5 nuclear emulsion (Ilford, Ilford, Essex, UK), developed after 4-5 days at $4{ }^{\circ} \mathrm{C}$, and counterstained with Meyer's haematoxylin. CTRP cells were scored as those that demonstrated sufficient grain density to outline the cell clearly. The number of CTRP cells present in ten random fields per coverslip at $\times 250$ magnification was counted.

\section{Statistical methods}

Differences between groups were analysed with Student's $t$-test.

\section{Results}

Like $1,25(\mathrm{OH})_{2} \mathrm{D}_{3}$, PTH stimulated both CTRP cell production and bone resorption in cultures of bone marrow cells (Fig. 1). The combination of maximal effective concentrations of the two hormones was not additive for either osteoclast induction or bone resorption. Indeed, bone resorption in cultures incubated with both 
hormones was if anything less than with $1,25(\mathrm{OH})_{2} \mathrm{D}_{3}$ alone.

When spleen cells from 4-day-old mice, in which the spleen is still a site of active haemopoiesis, were incubated at a similar density to bone marrow cells, no bone resorption was observed in the presence of either hormone. CTRP cells developed $\left(635 \pm 100\right.$ CTRP cells per $\mathrm{cm}^{2}$ (mean \pm S.E.M., $n=8$ cultures)) in cultures incubated with $1,25(\mathrm{OH})_{2} \mathrm{D}_{3}$, as previously reported (Owens et al. 1996), but were not induced by PTH in the haemopoietic spleen cell cultures.

To determine whether this difference in behaviour between bone marrow and spleen cells was attributable to differences in the responsiveness of the constituent haemopoietic precursor populations, or in the constituent stromal cell types that support osteoclastogenesis, we incubated cells from haemopoietic spleen at a (low) density at which they depend on the addition of stromal cells for haemopoiesis to occur, with osteoblastic UMR 106, spleen and bone marrow stromal cell lines. Cocultures of spleen stromal cell lines with low-density haemopoietic spleen cells generated substantial numbers of CTRP cells in response to $1,25(\mathrm{OH})_{2} \mathrm{D}_{3}$ (Figs 2 and 3), at least comparable with numbers seen in bone marrow cultures or observed using cell lines derived from bone marrow stroma (see below). The somewhat greater numbers observed in some such cultures compared with spleen itself incubated at high density is likely to be because haemopoiesis is more effective if haemopoietic cells are added to an established stromal cell layer (Dexter et al. 1977). Despite efficient CTRP cell production by $1,25(\mathrm{OH})_{2} \mathrm{D}_{3}$ in such cultures, however, very few CTRP cells were induced by PTH (Fig. 3). No bone resorption was observed in the presence of either hormone, nor in those cocultures incubated throughout in $1,25(\mathrm{OH})_{2} \mathrm{D}_{3}$, to which $\mathrm{PTH}$ was added for the final 7 days of incubation.

Haemopoietic spleen was also incubated at low density in coculture with bone marrow stromal-derived cell lines tsJ2 and tsJ4. Both cell lines were able to induce CTRP cell production and bone resorption with $1,25(\mathrm{OH})_{2} \mathrm{D}_{3}$ (Table 1). However, no CTRP cells or resorption were observed in cultures incubated with $\mathrm{PTH}$, and PTH did not significantly affect the response of tsJ2-spleen co-cultures to $1,25(\mathrm{OH})_{2} \mathrm{D}_{3}$.

Osteoblast-like UMR 106 cells induced extensive bone resorption in cocultures with low density haemopoietic spleen (Figs 4 and 5), and extensive ${ }^{125} \mathrm{I}$-CT binding was observed in autoradiographs. Large numbers of CTRP cells were induced by PTH, but very few were observed in control cultures.

The dynamics of the substantial levels of CTRP cell induction and bone resorption induced by UMR 106 cells were analysed in a time-course experiment (Fig. 6). By 7 days large numbers of CTRP cells were present in cultures incubated with PTH but not in controls. A small proportion of the bone surface had been resorbed after 7 days

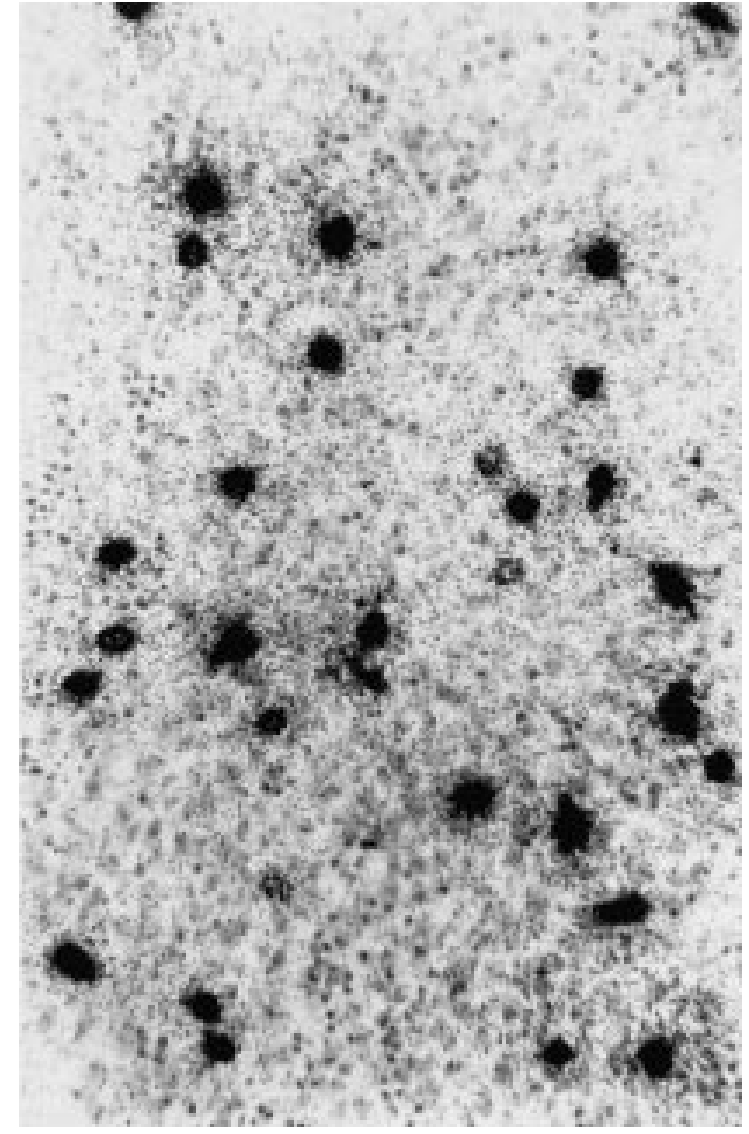

Figure 2 CTRP cells produced by incubation of haemopoietic spleen cells $\left(10^{5} /\right.$ well $)$ on spleen stromal cell line tsMS5.

Numerous ${ }^{125} \mathrm{I}$-CT-binding cells are present after 14 days in culture. Magnification $\times 130$.

of culture with PTH, after which time the rate of resorption increased rapidly.

Despite the very high levels of resorption induced by UMR 106 cells, no resorption was induced in haemopoietic spleen cells incubated in supernatant from UMR cells, or on UMR cells devitalised after incubation for $24 \mathrm{~h}$ in PTH. The differential patterns of hormonal responses are summarised in Table 2.

\section{Discussion}

It is believed that PTH increases the resorptive activity of pre-existing osteoclasts through a primary interaction with cells of the osteoblastic lineage. Much less is known, however, of the mechanisms by which PTH induces osteoclast formation. Osteoclasts form in haemopoietic tissue through a contact-dependent interaction between osteoclast precursors, which are ultimately derived from the haemopoietic stem cell, and the stromal cells of the haemopoietic microenvironment (Chambers 1992, Suda 

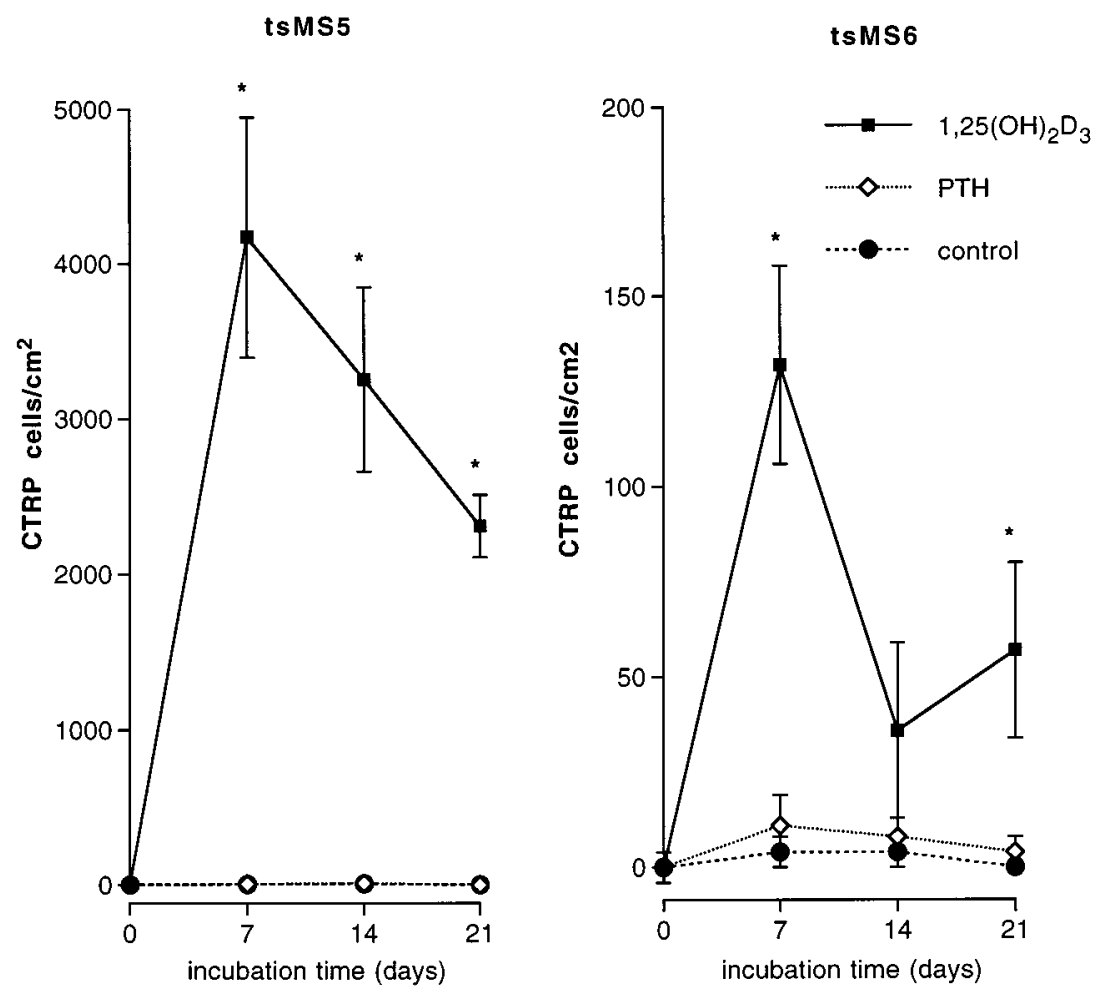

Figure 3 CTRP cell production in cocultures of haemopoietic spleen cells $\left(10^{5} /\right.$ well $)$ with spleen stromal cell lines. None of the cultures showed any evidence of bone resorption. Six cultures per variable. ${ }^{*} P<0 \cdot 01$ vs control.

et al. 1995). Stromal cells represent a diverse cell population that includes macrophages, fibroblasts, endothelial cells, adipocytes and, in bone marrow, osteoblastic cells. These stromal cells support haemopoiesis, which provides osteoclast precursors. Additionally, some stromal cells are capable of inducing haemopoietic precursors to differentiate into osteoclasts (Udagawa et al. 1989, Yamashita et al. 1990, Hiura et al. 1991, Chambers et al. 1993, Taylor et al. 1993, Quinn et al. 1994, Matsumoto et al. 1995, Feuerbach et al. 1997).

While it is known that PTH can induce osteoclast formation in bone marrow cultures (Takahashi et al. 1988b, Akatsu et al. 1989), little is known of the mechanisms involved, or the cell type that primarily responds to PTH in these heterogenous cultures. Some experiments using TRAP as a marker for osteoclasts suggest that a PTH response is needed in the stromal supportive cells; others attribute osteoclast formation to an action of PTH on haemopoietic precursors themselves (Takahashi et al. 1988a, Hakeda et al. 1989, Udagawa et al. 1989, Yamashita et al. 1990, Kaji et al. 1996, 1997). TRAP is not always a reliable marker for osteoclastic differentiation, however, and we have thus used bone resorption and ${ }^{125} \mathrm{I}-\mathrm{CT}$ autoradiographic detection of CTRP cells as

Table 1 Induction of osteoclastic differentiation by bone marrow stromal cell lines. Cells from haemopoietic spleen $\left(10^{5} /\right.$ well) were cocultured for 14 days with bone marrow stromal cell lines in the presence or absence of hormones. Figures represent means \pm S.E.M. derived from six cultures per variable in five (ts)2) and two (ts)4) separate experiments

\begin{tabular}{|c|c|c|c|c|}
\hline & tsJ $2+$ splee & & tsJ4+splee & \\
\hline & CTRP & Bone resorption & CTRP & Bone resorption \\
\hline Control & 0 & 0 & 0 & 0 \\
\hline $1,25(\mathrm{OH})_{2} \mathrm{D}_{3}$ & $790 \pm 83$ & $25 \cdot 9 \pm 12 \cdot 3$ & $880 \pm 160$ & $2 \cdot 5 \pm 1 \cdot 1$ \\
\hline PTH & 0 & 0 & 0 & 0 \\
\hline $\mathrm{PTH}+1,25(\mathrm{OH})_{2} \mathrm{D}_{3}$ & $996 \pm 153$ & $32 \cdot 0 \pm 4 \cdot 4$ & ND & ND \\
\hline
\end{tabular}

$\mathrm{ND}=$ not determined 


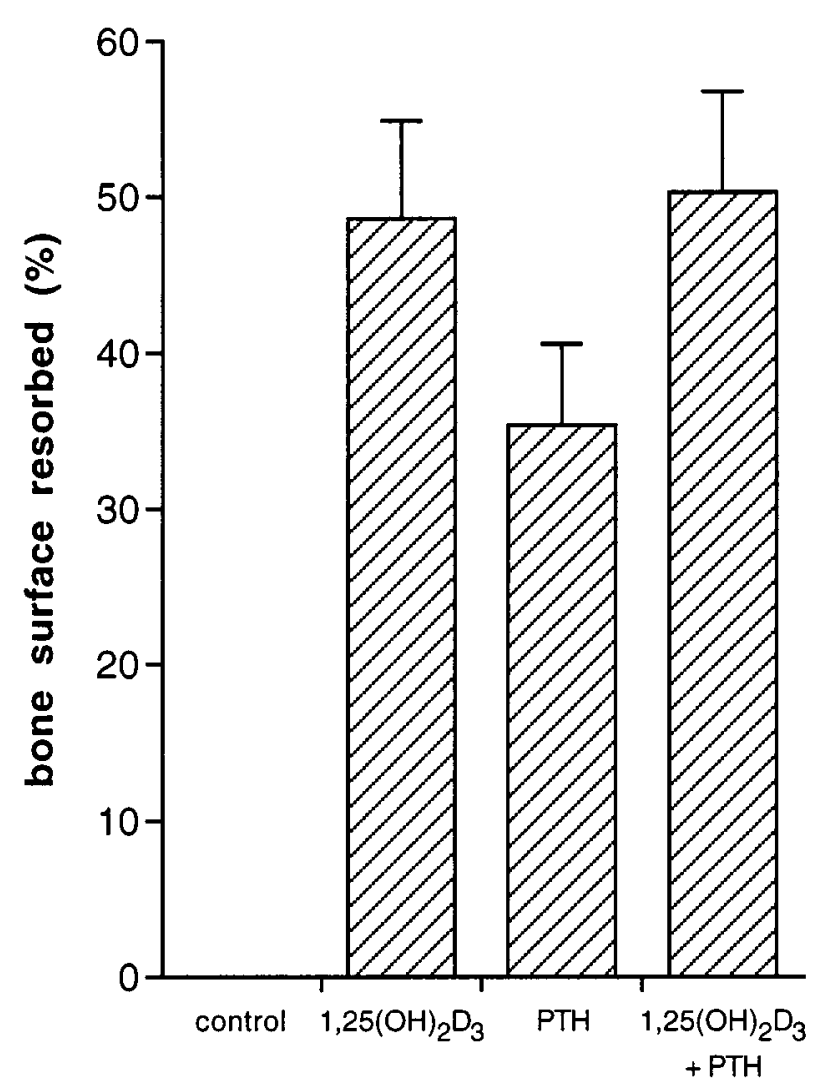

Figure 4 Bone resorption after incubation of bone slices with UMR 106 cells and haemopoietic spleen cells $\left(10^{5} /\right.$ well) for 14 days. Six cultures per variable. No excavations were observed in cultures incubated without hormones.

markers of osteoclastic differentiation to analyse the responses of haemopoietic tissue to $\mathrm{PTH}$. We found that both PTH and $1,25(\mathrm{OH})_{2} \mathrm{D}_{3}$ were able to induce CTRP cell production in bone marrow cultures, but while $1,25(\mathrm{OH})_{2} \mathrm{D}_{3}$ induced CTRP cells in haemopoietic spleen cultures, as previously found (Owens et al. 1996), PTH was without effect.

PTH induced substantial numbers of CTRP cells from bone marrow, suggesting that its failure to induce CTRP cells in spleen cultures reflects a difference not in potency but in pattern of responsiveness. A difference in the pattern rather than potency of responsiveness was even more striking in cocultures. In contrast to the comparable levels of osteoclastic differentiation induced by $\mathrm{PTH}$ vs $1,25(\mathrm{OH})_{2} \mathrm{D}_{3}$ in bone marrow cultures, and in UMR 106-spleen cell cocultures, $1,25(\mathrm{OH})_{2} \mathrm{D}_{3}$ induced CTRP cell numbers at least three orders of magnitude greater than did PTH in cocultures supported by spleen stromal cells.

The experiments also suggest that the differences in responses to $\mathrm{PTH}$ and $1,25(\mathrm{OH})_{2} \mathrm{D}_{3}$ are attributable to stromal rather than haemopoietic cells; in cocultures of haemopoietic spleen cells with stromal/osteoblastic cells, the cultures expressed some or all of the hormonal responsiveness shown by the tissue of origin of the stromal cells. This suggests that the ability of PTH to induce osteoclasts in cocultures of UMR cells with spleen cells depends on an action of PTH on UMR 106 cells. Conversely, the failure of spleen stromal cells, which are capable of osteoclast induction, to do so in response to $\mathrm{PTH}$ suggests that spleen stromal cells fail to provide an osteoclastinductive environment in response to PTH. Similar conclusions have been reached before using TRAP as a marker for osteoclastic differentiation (Takahashi et al. 1988b, Udagawa et al. 1989).

Although tsJ2 and tsJ4, which were derived from bone marrow stroma, were able to confer on spleen cells the hormonal responsiveness to $1,25(\mathrm{OH})_{2} \mathrm{D}_{3}$ of bone marrow cultures, unlike bone marrow they did not induce osteoclast formation with PTH. We and others (Udagawa et al. 1989, Yamashita et al. 1990, Hiura et al. 1991, Chambers et al. 1993, Taylor et al. 1993, Matsumoto et al. 1995, Feuerbach et al. 1997) have noted heterogeneity in the osteoclast-inductive abilities of cell lines derived from bone marrow stroma, which probably reflects the diversity of this cell population. It is tempting to speculate that these distinct patterns of hormone responsiveness and osteoclastinductive and activational abilities reflect the existence in bone and bone marrow of corresponding subpopulations specialised for regulation of different aspects in vivo of the overall process of osteoclast formation, activation, and hormonal responsiveness.

As previously reported (Owens et al. 1996), we found that spleen cells incubated with $1,25(\mathrm{OH})_{2} \mathrm{D}_{3}$ at high density alone, or at lower density on spleen stromal cell lines, produced considerable numbers of CTRP cells, but did not induce bone resorption. Despite lack of resorption, such cells appear to be mature osteoclasts, since they can be induced by addition of osteoblasts to resorb bone at a daily rate, during the first $24 \mathrm{~h}$, equivalent to that of pre-existing osteoclasts (Owens et al. 1996). We found that $\mathrm{PTH}$, like $1,25(\mathrm{OH})_{2} \mathrm{D}_{3}$, was unable to induce bone resorption in such cultures. This lends further support to the view that PTH does not induce osteoclastic bone resorption through a primary hormonal interaction with osteoclasts.

There are several reports in the literature that haemopoietic blast cells have PTH receptors, and produce TRAP-positive cells in culture (Hakeda et al. 1989, Kaji et al. 1996, 1997). However, PTH was unable to induce CTRP cells, a more reliable marker for osteoclast differentiation (Hattersley \& Chambers 1989c) in cocultures of haemopoietic spleen cells with either spleen stromal cells, tsJ 2 or tsJ4 bone marrow stromal cells. Because these cultures are competent to generate osteoclasts in response to $1,25(\mathrm{OH})_{2} \mathrm{D}_{3}$, this suggests that induction of osteoclastic differentiation by PTH is not due to a direct effect of PTH on precursors. TRAP can be induced in 

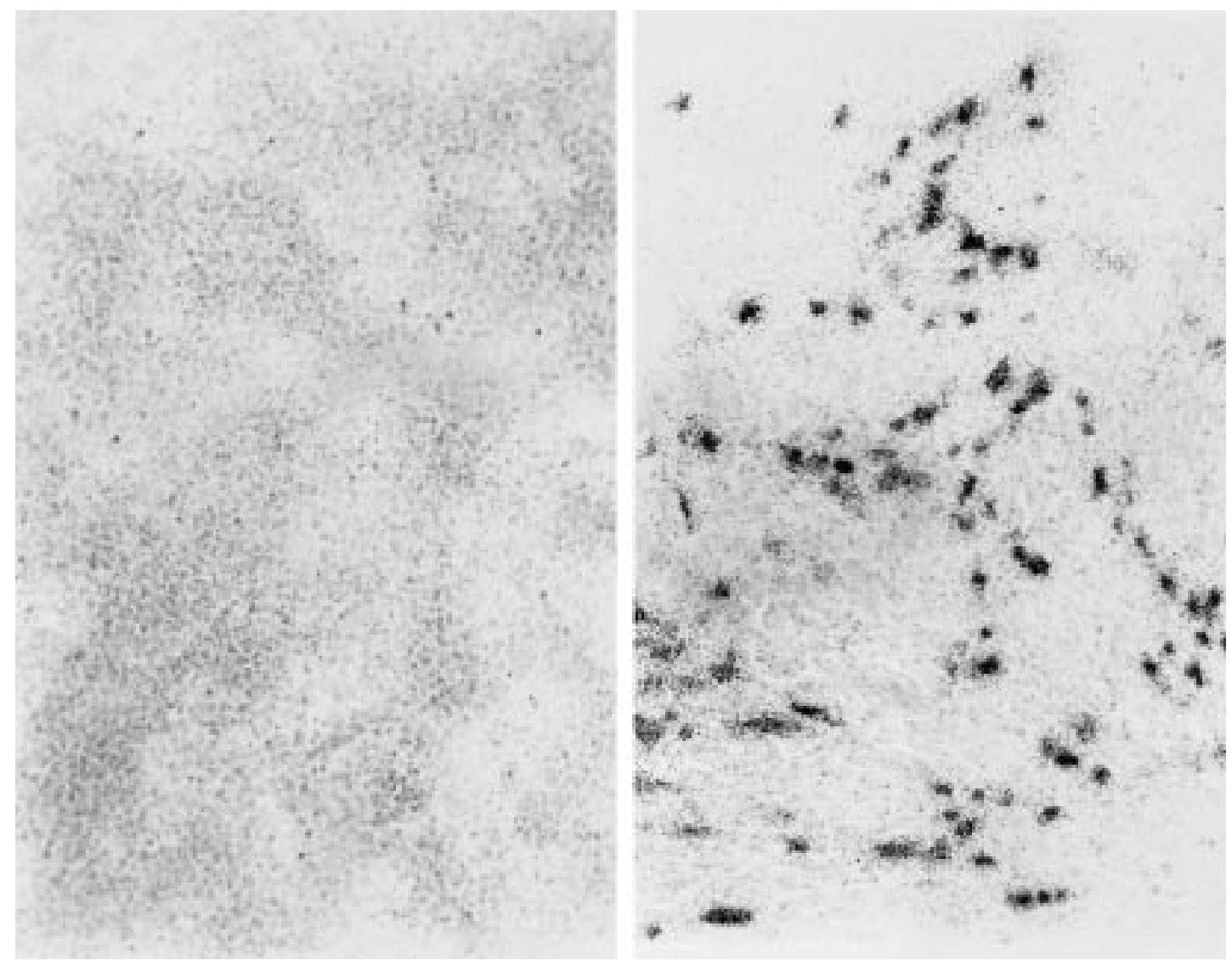

Figure $5{ }^{125} \mathrm{I}-\mathrm{CT}$ autoradiographs of UMR 106-haemopoietic spleen cell cocultures after 7 days incubation with (left) or without (right) PTH. Numerous CTRP cells are observed in cultures incubated with PTH. Magnification $\times 130$.

mononuclear phagocytes by stimuli unrelated to osteoclast induction (Yam et al. 1971, Radzun et al. 1983, Troy et al. 1985, Bianco et al. 1987, 1988), and the PTH/PTHrP (PTH-related peptide) receptor mediates many responses unrelated to osteoclast regulation. Alternatively, TRAP induction might represent partial osteoclastic differentiation which for completion needs an additional signal to be activated by PTH in stromal cells. Thus, the significance of the induction of TRAP by PTH in haemopoietic cells remains uncertain.

Receptors for $1,25(\mathrm{OH})_{2} \mathrm{D}_{3}$ are ubiquitous, with the probable and paradoxical exception of the osteoclast (Merke et al. 1986). The dependency of osteoclast induction by $\mathrm{PTH}$ on a response in stromal cells suggests that osteoclast-inductive capacity is not a constitutive function of these stromal cells but requires hormone induction. This implies a similar inductive role for $1,25(\mathrm{OH})_{2} \mathrm{D}_{3}$ in these stromal cells. In addition, $1,25(\mathrm{OH})_{2} \mathrm{D}_{3}$ is known to affect the targets for differentiation induction by stromal cells; it suppresses proliferation and induces differentiation in cells of the mononuclear phagocyte series, and it is possible that this action contributes to osteoclast differentiation, particu- larly since differentiated features induced in mononuclear phagocytes by the hormone include osteoclastic characteristics such as multinuclearity, $\alpha_{v} \beta_{3}$ expression, and TRAP. However, these characteristics are also observed in activated macrophages in circumstances unrelated to bone resorption and their induction does not necessarily imply that the hormone favours osteoclastic vs macrophagic differentiation. We noted in bone marrow cultures an inverse relationship between CTRP cell numbers and bone resorption for cultures incubated with $1,25(\mathrm{OH})_{2} \mathrm{D}_{3}$ compared with PTH. This pattern could be accounted for as a PTH-like action of $1,25(\mathrm{OH})_{2} \mathrm{D}_{3}$ on the ability of stromal cells to induce osteoclasts, combined with a direct anti-proliferative, differentiation-inductive action of $1,25(\mathrm{OH})_{2} \mathrm{D}_{3}$ on osteoclast precursors. The noted relative reduction in CTRP cell numbers does not support the possibility that $1,25(\mathrm{OH})_{2} \mathrm{D}_{3}$ favours osteoclastic versus macrophagic differentiation amongst bipotential precursors. Thus, it may be that $1,25(\mathrm{OH})_{2} \mathrm{D}_{3}$ acts on mononuclear phagocyte precursors as in other cell types, not to direct differentiation, but to increase differentiation directed by other stimuli. 

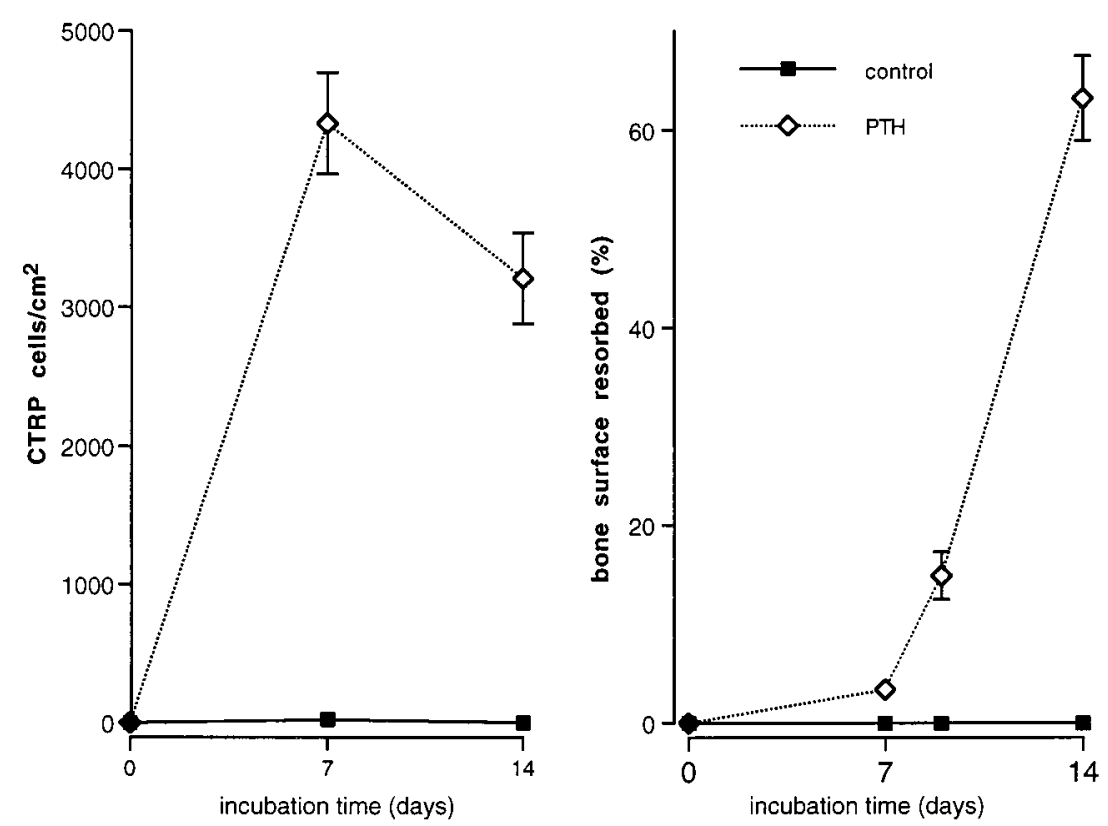

Figure 6 Induction of CTRP cells and bone resorption in cocultures of UMR 106 cells with haemopoietic spleen cells. Twelve cultures per variable.

Table 2 Patterns of CTRP cell production and bone resorption in murine bone marrow and spleen cultures

\begin{tabular}{|c|c|c|c|}
\hline & Hormone & $\begin{array}{l}\text { CTRP } \\
\text { cells }\end{array}$ & $\begin{array}{l}\text { Bone } \\
\text { resorption }\end{array}$ \\
\hline \multicolumn{4}{|l|}{ Culture } \\
\hline High density spleen & $\begin{array}{l}1,25(\mathrm{OH})_{2} \mathrm{D}_{3} \\
\text { PTH }\end{array}$ & $\begin{array}{l}+ \\
-\end{array}$ & $\begin{array}{l}- \\
-\end{array}$ \\
\hline $\begin{array}{l}\text { Cocultures of low } \\
\text { density spleen with: }\end{array}$ & & & \\
\hline tsMS5/tsMS6 & $\begin{array}{l}1,25(\mathrm{OH})_{2} \mathrm{D}_{3} \\
\text { PTH }\end{array}$ & $\begin{array}{l}+ \\
-\end{array}$ & $\begin{array}{l}- \\
-\end{array}$ \\
\hline tsJ2/tsJ4 & $\begin{array}{l}1,25(\mathrm{OH})_{2} \mathrm{D}_{3} \\
\text { PTH }\end{array}$ & $\begin{array}{l}+ \\
-\end{array}$ & $\begin{array}{l}+ \\
-\end{array}$ \\
\hline UMR 106 & $\begin{array}{l}1,25(\mathrm{OH})_{2} \mathrm{D}_{3} \\
\text { PTH }\end{array}$ & $\begin{array}{l}+ \\
+\end{array}$ & $\begin{array}{l}+ \\
+\end{array}$ \\
\hline $\begin{array}{l}\text { High density bone } \\
\text { marrow }\end{array}$ & $\begin{array}{l}1,25(\mathrm{OH})_{2} \mathrm{D}_{3} \\
\text { PTH }\end{array}$ & $\begin{array}{l}+ \\
+\end{array}$ & $\begin{array}{l}+ \\
+\end{array}$ \\
\hline
\end{tabular}

The available data neither exclude nor favour a dependency for osteoclast formation on a direct action of $1,25(\mathrm{OH})_{2} \mathrm{D}_{3}$ and/or PTH on osteoclastic precursors. They do nevertheless suggest that such putative actions alone do not account for the induction of osteoclastic differentiation in cocultures of stromal cells with haemopoietic cells. Our data suggest that osteoclast induction requires a response to PTH in stromal-type cells. The substantial osteoclast-inductive response of UMR 106 cells to PTH identifies this as a model system in which to analyse the differential behaviour induced by PTH that enables osteoclast formation. Moreover, such an analysis should be facilitated by the identification of spleen and bone marrow stromal cell types with distinctive patterns of hormonal responsiveness and differential actions on osteoclast formation and activation.

\section{Acknowledgement}

This work was supported by The Wellcome Trust, London, UK.

\section{References}

Abe E, Miyaura C, Tanaka H, Shiina Y, Kuribayashi T, Suda S, Nishii Y, DeLuca H \& Suda T 1983 1 $\alpha, 25$-dihydroxyvitamin $\mathrm{D}_{3}$ promotes fusion of mouse alveolar macrophages both by a direct mechanism and by a spleen cell-mediated indirect mechanism. Proceedings of the National Academy of Sciences of the USA $\mathbf{8 0}$ $5583-5587$.

Agarwala N \& Gay CV 1992 Specific binding of parathyroid hormone to living osteoclasts. Journal of Bone and Mineral Research 7 531-539.

Akatsu T, Takahashi N, Udagawa N, Sato K, Nagata N, Moseley JM, Martin TJ \& Suda T 1989 Parathyroid hormone (PTH)-related protein is a potent stimulator of osteoclast-like multinucleated cell formation to the same extent as PTH in mouse marrow cultures. Endocrinology 125 20-27.

Bar-Shavit Z, Teitelbaum SL, Reitsma P, Hall A, Pegg LE, Trial J \& Kahn AJ 1983 Induction of monocytic differentiation and bone resorption by 1,25-dihydroxyvitamin $\mathrm{D}_{3}$. Proceedings of the National Academy of Sciences of the USA 80 5907-5911.

Baron R \& Vignery A 1981 Behavior of osteoclasts during a rapid change in their number induced by high doses of parathyroid hormone or calcitonin in intact rats. Metabolic Bone Disease and Related Research 2 339-346. 
Bianco P, Costantini M, Dearden LC \& Bonucci E 1987 Expression of tartrate-resistant acid phosphatase in bone marrow macrophages. Basic Applied Histochemistry 31 433-440.

Bianco P, Ballanti P \& Bonucci E 1988 Tartrate-resistant acid phosphatase activity in rat osteoblasts and osteocytes. Calcified Tissue International 43 167-171.

Billecocq A, Emanuel JR, Levenson R \& Baron R 1990 1a,25dihydroxyvitamin $\mathrm{D}_{3}$ regulates the expression of carbonic anhydrase II in nonerythroid avian bone marrow cells. Proceedings of the National Academy of Sciences of the USA 87 6470-6474.

Bingham PJ, Brazell IA \& Owen M 1969 The effect of parathyroid extract on cellular activity and plasma calcium levels in vivo. Journal of Endocrinology 45 387-400.

Chambers TJ 1980 The cellular basis of bone resorption. Clinical Orthopaedics and Related Research 151 283-293.

Chambers TJ 1992 Regulation of osteoclast development and function. In Biology and Physiology of the Osteoclast, pp 105-128. Eds BR Rifkin \& CV Gay. Boca Raton: CRC Press.

Chambers TJ, McSheehy PMJ, Thomson BM \& Fuller K 1985 The effect of calcium-regulating hormones and prostaglandins on bone resorption by osteoclasts disaggregated from neonatal rabbit bones. Endocrinology 116 234-239.

Chambers TJ, Owens JM, Hattersley G, Jat PS \& Noble MD 1993 Generation of osteoclast-inductive and osteoclastogenic cell lines from the $H-2 K^{b} t s A 58$ transgenic mouse. Proceedings of the National Academy of Sciences of the USA 90 5578-5582.

Dexter TM, Allen TD \& Lajtha LG 1977 Conditions controlling the proliferation of haemopoietic stem cells in vitro. Journal of Cellular Physiology 91 335-344.

Feuerbach D, Loetscher E, Buerki K, Sampath TK \& Feyen JHM 1997 Establishment and characterization of conditionally immortalized stromal cell lines from a temperature-sensitive T-Ag transgenic mouse. Journal of Bone and Mineral Research 12 179-190.

Fuller K, Owens JM, Jagger CJ, Wilson A, Moss R \& Chambers TJ 1993 Macrophage colony-stimulating factor stimulates survival and chemotactic behavior in isolated osteoclasts. Journal of Experimental Medicine 178 1733-1744.

Hakeda Y, Hiura K, Sato T, Okazaki R, Matsumoto T, Ogata E, Ishitani R \& Kumegawa M 1989 Existence of parathyroid hormone binding sites on murine hemopoietic blast cells. Biochemical and Biophysical Research Communications 163 1481-1486.

Hattersley G \& Chambers TJ 1989a Generation of osteoclastic function in mouse bone marrow cultures: multinuclearity and tartrate-resistant acid phosphatase are unreliable markers for osteoclastic differentiation. Endocrinology 124 1689-1696.

Hattersley G \& Chambers TJ 1989 b Generation of osteoclasts from hemopoietic cells and a multipotential cell line in vitro. Journal of Cellular Physiology 140 478-482.

Hattersley G \& Chambers TJ 1989 c Calcitonin receptors as markers for osteoclastic differentiation: correlation between generation of bone-resorptive cells and cells that express calcitonin receptors in mouse bone marrow cultures. Endocrinology 125 1606-1612.

Hattersley G \& Chambers TJ 1990 Effects of interleukin 3 and of granulocyte-macrophage and macrophage colony stimulating factors on osteoclast differentiation from mouse hemopoietic tissue. Journal of Cellular Physiology 142 201-209.

Hiura K, Sumitani K, Kawata T, Higashino K, Okawa M, Sato T, Hakeda Y \& Kumegawa M 1991 Mouse osteoblastic cells (MC3T3-E1) at different stages of differentiation have opposite effects on osteoclastic cell formation. Endocrinology 128 1630-1637.

Inoue H, Tanaka N \& Uchiyama C 1995 Parathyroid hormone increases the number of tartrate-resistant acid phosphatase-positive cells through prostaglandin $\mathrm{E}_{2}$ synthesis in adherent cell culture of neonatal rat bones. Endocrinology 136 3648-3656.

Kaji H, Sugimoto T, Kanatani M, Miyauchi A, Kimura T, Sakakibara S, Fukase M \& Chihara K 1994 Carboxyl-terminal parathyroid hormone fragments stimulate osteoclast-like cell formation and osteoclastic activity. Endocrinology 134 1897-1904.
Kaji H, Sugimoto T, Kanatani M, Fukase M \& Chihara K 1995 Carboxyl-terminal peptides from parathyroid hormone-related protein stimulate osteoclast-like cell formation. Endocrinology 136 842-848.

Kaji H, Sugimoto T, Kanatani M, Nasu M \& Chihara K 1996 Estrogen blocks parathyroid hormone (PTH)-stimulated osteoclastlike cell formation by selectively affecting PTH-responsive cyclic adenosine monophosphate pathway. Endocrinology 137 2217-2224.

Kaji H, Sugimoto T, Kanatani M, Nishiyama K \& Chihara K 1997 Dexamethasone stimulates osteoclast-like cell formation by directly acting on hemopoietic blast cells and enhances osteoclast-like cell formation stimulated by parathyroid hormone and prostaglandin $\mathrm{E}_{2}$. Journal of Bone and Mineral Research 12 734-741.

Matsumoto HN, Tamura M, Denhardt DT, Obinata M \& Noda M 1995 Establishment and characterization of bone marrow stromal cell lines that support osteoclastogenesis. Endocrinology 136 4084-4091.

Medhora MM, Teitelbaum S, Chappel J, Alvarez J, Mimura H, Ross FP \& Hruska K 1993 1a,25-dihydroxyvitamin $D_{3}$ up-regulates expression of the osteoclast integrin $\alpha_{\mathrm{v}} \beta_{3}$. Journal of Biological Chemistry 268 1456-1461.

Merke J, Klaus G, Hügel U, Waldherr R \& Ritz E 1986 No 1,25dihydroxyvitamin $\mathrm{D}_{3}$ receptors on osteoclasts of calciumdeficient chicken despite demonstrable receptors on circulating monocytes. Journal of Clinical Investigation 77 312-314.

Modderman WE, Tuinenburg-Bol Raap AC \& Nijweide PJ 1991 Tartrate-resistant acid phosphatase is not an exclusive marker for mouse osteoclasts in cell culture. Bone 12 81-87.

Owens JM, Gallagher AC \& Chambers TJ 1996 Bone cells required for osteoclastic resorption but not for osteoclastic differentiation. Biochemical and Biophysical Research Communications 222 225-229.

Quinn JMW, McGee JOD \& Athanasou NA 1994 Cellular and hormonal factors influencing monocyte differentiation to osteoclastic bone-resorbing cells. Endocrinology 134 2416-2423.

Radzun HJ, Kreipe H \& Parwaresch MR 1983 Tartrate-resistant acid phosphatase as a differentiation marker for the human mononuclear phagocyte system. Hematological Oncology 1 321-327.

Rao LG, Murray TM \& Heersche TNM 1983 Immunohistochemical demonstration of parathyroid hormone binding to specific cell types in fixed rat bone tissue. Endocrinology 113 805-810.

Rodan GA \& Martin TJ 1981 The role of osteoblasts in hormonal control of bone resorption. Calcified Tissue International 33 349-351.

Rouleau MF, Warshawsky H \& Goltzman D 1986 Parathyroid hormone binding in vivo to renal, hepatic and skeletal tissues of the rat using a radioautographic technique. Endocrinology 118 919-931.

Rouleau MF, Mitchell J \& Goltzman D 1988 In vivo distribution of parathyroid hormone receptors in bone: evidence that a predominant osseous target cell is not the mature osteoblast. Endocrinology 123 187-191.

Rouleau MF, Mitchell J \& Goltzman D 1990 Characterization of the major parathyroid hormone target cell in the endosteal metaphysis of rat long bones. Journal of Bone and Mineral Research 5 1043-1053.

Snipes RG, Lam KW, Dodd RC, Gray TK \& Cohen MS 1986 Acid phosphatase in mononuclear phagocytes and the U937 cell line: monocyte-derived macrophages express tartrate-resistant acid phosphatase. Blood 67 729-734.

Suda T, Takahashi N \& Martin TJ 1995 Modulation of osteoclast differentiation: update. In Endocrine Reviews Monographs, vol 4, pp 266-270. Eds DD Bikle \& A Negrovilar. Bethesda, MD: Endocrine Society.

Takahashi N, Akatsu T, Udagawa N, Sasaki T, Yamaguchi A, Moseley JM, Martin TJ \& Suda T 1988a Osteoblastic cells are involved in osteoclast formation. Endocrinology 123 2600-2602.

Takahashi N, Yamana H, Yoshiki S, Roodman DG, Mundy GR, Jones SJ, Boyde A \& Suda T 1988 b Osteoclast-like cell formation and its regulation by osteotropic hormones in mouse marrow cultures. Endocrinology 122 1373-1382. 
Taylor LM, Turksen K, Aubin JE \& Heersche JNM 1993 Osteoclast differentiation in cocultures of a clonal chondrogenic cell line and mouse bone marrow cells. Endocrinology 133 2292-2300.

Teti LT, Rizzoli R \& Zambonin ZA 1991 Parathyroid hormone binding to cultured avian osteoclasts. Biochemical and Biophysical Research Communications 174 1217-1222.

Troy K, Cuttner J, Reilly M, Grabowski G \& Desnick R 1985 Tartrate-resistant acid phosphatase staining of monocytes in Gaucher's disease. American Journal of Hematology 19 237-244.

Udagawa N, Takahashi N, Akatsu T, Sasaki T, Yamaguchi A, Kodama H, Martin TJ \& Suda T 1989 The bone marrow-derived stromal cell lines MC3T3-G2/PA6 and ST2 support osteoclast-like cell differentiation in cocultures with mouse spleen cells. Endocrinology 125 1805-1813.

Yam LT, Li CY \& Lam KW 1971 Tartrate-resistant acid phosphatase isoenzyme in the reticulum cells of leukemic reticuloendotheliosis. New England Journal of Medicine 284 357-360.

Yamashita T, Asano K, Takahashi N, Akatsu T, Udagawa N, Sasaki T, Martin TJ \& Suda T 1990 Cloning of an osteoblastic cell line involved in the formation of osteoclast-like cells. Journal of Cellular Physiology 145 587-595.

Received 9 January 1998

Accepted 21 April 1998 